\title{
MOTIVASI INVESTASI, FINANCIAL LITERACY, DAN PERSEPSI RESIKO PENGARUHNYA TERHADAP MINAT BERINVESTASI DI PASAR MODAL
}

\author{
Hikmah $^{1}$ \\ ${ }^{1}$ Universitas Putera Batam \\ hikmahupb@gmail.com
}

\begin{abstract}
ABSTRAK
Indonesia salah satu negara dimana secara finansial sebagain besar penduduknya tetap melakukan investasi jangka pendek atau menabung. Apabila dilihat perbedaannya dengan beberapa negara yang sangat maju maka investasinya pada pada jangka panjang atau investasi. Adanya pemahaman masyarakat terhadap pengelolaan finansial sehingga masyarakat mampu menyisihkan sebagain pendapatan yang diperoleh dalam melakukan kegiatan investasi. Pada saat sekarang sudah banyak efek keuangan yang ada baik dalam pasar uang ataupun dalam pasar modal, contohnya pada pasar uang seperti tabungan dan deposito berjangka, sedangkan pada pasar modal terdapat efek seperi obligasi dan saham dari berbagai perusahaan ataupun milik pemerintah. Dalam penelitian ini bertujuan untuk mengetahui motivasi investasi, literasi keuangan dan persepsi resiko pengaruhnya terhadap minat investasi masyarakat pada pasar modal di Kota Batam. Populasi dalam penelitian ini adalah kecamatan Sagulung, Dengan sampel dalam penelitian ini 204 respoenden. Reseponden dalam penelitian ini adalah masyarakat yang berminat melakukan investasi di pasar modal. Teknik penentuan sampel yang digunakan adalah purposive sampling. Adapun metode analisis yang digunakan mengunakan SEM dengan aplikasi SmartPLS. Hasil penelitian menunjukkan bahwa motivasi investasi berpengaruh positif dan signifikan terhadap minat investasi, literasi keuangan berpengaruh positif dan signifikan terhadap minat investasi, persepsi resiko berpengaruh positif dan signifikan terhadap minat investasi di kota Batam.
\end{abstract}

Kata kunci : Motivasi Investasi, Financial Literacy, Persepsi Resiko, Minat berinvestasi.

\begin{abstract}
Indonesia is one of the countries where financially most of the population continues to make short-term investments or save. If you look at the difference with some very developed countries, the investment is in the long term or investment. The existence of public understanding of financial management so that people are able to set aside a portion of the income earned in conducting investment activities. At present, there are many financial effects that exist both in the money market and in the capital market, for example in the money market such as savings and time deposits, while in the capital market there are securities such as bonds and shares from various companies or government owned. This study aims to determine investment motivation, financial literacy and risk perception of its influence on public investment interest in the capital market in Batam City. The population in this study is the sub-district of Sagulung, with 204 respondents as the sample in this study. The respondents in this study are people who are interested in investing in the capital market. The sampling technique used is purposive sampling. The analysis method used is SEM with the SmartPLS application. The results show that investment motivation has a positive and significant effect on investment interest, financial literacy has a positive and significant effect on investment interest, risk perception has a positive and significant effect on investment interest in Batam city.
\end{abstract}

Keywords: Invest Motivation, Financial Literacy, Risk Perceived, Intention to Invest

\section{PENDAHULUAN}


Prosiding The 1st National Conference on Applied Business, Education, \& Technology (NCABET)"

Unversitas Bina Bangsa 2021

DOI Article : 10.46306/ncabet.v1i1.41

Indonesia salah satu negara dimana secara finansial sebagain besar penduduknya tetap melakukan investasi jangka pendek atau menabung. Apabila dilihat perbedaannya dengan beberapa negara yang sangat maju maka investasinya pada pada jangka panjang atau investasi. Adanya pemahaman masyarakat terhadap pengelolaan finansial sehingga masyarakat mampu menyisihkan sebagain pendapatan yang diperoleh dalam melakukan kegiatan investasi. Dikarenakan hal tersebut, sangat dibutuhkan pendidikan kepada masyarakat luas yang dilakukan secara terus menerus dan konsisten untuk memberikan perubahan pola pemikiran masyarakat dari kebiasan menabung beralih ke investasi di pasar modal. Pada saat sekarang sudah banyak efek keuangan yang ada baik dalam pasar uang ataupun dalam pasar modal, contohnya pada pasar uang seperti tabungan dan deposito berjangka, sedangkan pada pasar modal terdapat efek seperi obligasi dan saham dari berbagai perusahaan ataupun milik pemerintah. Keuntungan instrumen keuangan pasar modal paling tinggi, akan tetapi juga memiliki risiko paling tinggi. Pada bulan oktober 2020, Jumlah perusahaan yang sudah go public yang terdaftar di IDX sebanyak 709 perusahaan dari berbagai macam sektor. Dengan pertambahan perusahaan yang sudah go public tersebut bisa menjadi salah satu motivasi bagi calon investor untuk melakukan investasi pasar modal melalui instrumen atau efek yaitu saham.

Tabel 1 Data Jumlah Investor di Indonesia

\begin{tabular}{|c|c|}
\hline Tahun & $\begin{array}{c}\text { Jumlah Investor } \\
\text { (Orang) }\end{array}$ \\
\hline 2017 & 1.122 .668 \\
\hline 2018 & 1.617 .367 \\
\hline 2019 & 2.484 .354 \\
\hline 2020 & 3.880 .753 \\
\hline Feb 2021 & 4.515 .103 \\
\hline
\end{tabular}

Sumber: KSEI, 2021

PT. KSEI (Kustodian Sentral Efek Indonesia) telah mengumumkan tentang pada single investor identification berjumlah 3,58 juta orang. Pada tahun 2019 tercatat bahwa single investor identification ( SID) sebanyak 2.4484.354 SID, sedangkan pada tahun 2020 ada sebanyak 4.515.103 SID, jumlah tingkat pertumbuhan adalah jumlah single investor identification yang melakukan investasi. Sementara itu dari jumlah tersebut diantaranya adalah investor ritel, dan sisanya sebanyak 32.183 merupakan investor institusi.di Kustodian Sentral Efek Indonesia (KSEI, 2021). Dimana dari jumlah tersebut, sebesar 99,24\% merupakan investor domestik dan sisanya investor asing. Berdasarkan data tersebut bisa dikatakan bahwa sebagian masyarakat yang ada di Indonesia belum tertarik untuk melakukan investasi danaya ke investasi jangka menengah dan jangka panjang disebabkan oleh adanya pertimbangan dari individu atau masyarakat. Rendahya minat masyarakat ini disebabkan karena banyak faktor. 
Salah satunya didukung oleh faktor masih rendahnya tingkat kesadaran masyarakat akan pentingnya melakukan investasi di masa yang akan datang melalui investasi jangka panjang.

Pada dasarnya masyarakat telah memiliki minat untuk melakukan investasi pada pasar modal. Tetapi, mereka memiliki beberapa rintangan ataupun kendala yang dihadapi khususnya bagi investor yang baru. Apabila para investor yang pemula belum memahami dengan baik tata cara dalam berinvestasi dan kemungkinan resiko yang akan dihadapi. (Rui, 2019). Salah satu faktor yang lain yang sangat mempengaruhi minat berinvestasi yaitu karena investasi sebagai sesuatu yang masih dikatakan tidak terlalu terkenal di masyarakat Indonesia apabila dilihat perbandingannya pada negara lain, antusiasme masyarakat Indonesia untuk melakukan investasi dikatakan sangat tergolong rendah. Tingkat antusisme masyarakat yang rendah tersebut dipengaruhi oleh kurangnya pengetahuan tentang investasi yang ada pada pasar modal mengakibatkan pada akhirnya masyarakat kurang memiliki motivasi dalam berinvestasi pada pasar jangka panjang. Selain disebabkan pengetahuan dan motivasi, faktor lain yang berpengaruh adalah literasi keuangan. Berdasarkan data survey diatas ditunjukkan bahwa pengetahuan dan pemahaman masyarakat tentang literasi keuangan pada masyarakat masih sangat kurang hal ini diikuti juga dengan rendanya pengetahuan tentang inklusi keuangan Salah satu yang menjadi hambatan berkembangnya investor di yang ada di pasar modal pasar saham dipicu adanya kesalahan pola pikir masyarakat yang mengatakan bahwa ketika melakukan investasi pada pasar modal maka akan melakukan kegiatan yang sama seperti melakukan judi (Saputra, 2018). Padahal masyarakat seharusnya tidak perlu memiliki pola pikir seperti itu karena kata“high risk high return", merupakan anggapan dari investor yang memiliki saham di pasar modal, dimana investasi tersebut hanya untuk para yang memburu capital gain dari saham yang dimilikinya. Demikian juga adanya anggapan bahawa apabila suatu saat mendapatkan hasil yang menguntungkan maka selanjutnya nanti akan mendapatkan kerugian juga, padahal itu adalah anggapan yang sangat salah.

Minat masyarakat dalam melakukan investasi pada pasar modal akan pada akhirnya akan memotivasi seseorang untuk bisa dan berani berinvestasi. Hal ini terbukti bahawa apabila individu memiliki ketertarikan untuk berinvestasi, maka pastinya individu atau masyarakat bisa melaksanakan kegaiatan-kegiatan dalam rangka pemenuhan keburtuhan masyarakat atau sesoerang untuk berinvestasi misalnya keikutsertaan dalam mengikuti pelatihan, kegiatan workshop dan tentang investasi.Motivasi merupakan suatu proses pemberian dorongan yang akan menentukan arah, tujuan seseorang pada kegiatan meraih tujuan serta pengaruhnya pada psikologi seseorang (Saputra, 2018). Adapun indikator motivasi investasi yaitu (Listyani et al., 2019):

1. Motivasi diawali dengan adanya perubahan dorongan pada diri individu 
Prosiding The 1st National Conference on Applied Business, Education, \& Technology (NCABET)"

Unversitas Bina Bangsa 2021

DOI Article : 10.46306/ncabet.v1i1.41

2. Motivasi dapat dilihat melalui munculnya suatu rasa yang mengarahkan pola perilaku atau tingkah individu

3. Motivasi dilakukan dengan melakukan aktivitas untuk meraih tujuan

Literasi keuangan menganalisis mengenai pengetahuan tentang keuangan, kemampuan dalam melakukan komunikasi tentang berbagai konsep keuangan, kemampuan dalam melakukan pengelolaan finansial individu, pemahaman dalam melakukan sebuah keputusan yang berkaitan dengan keuangan, dan memiliki kepercayaan diri untuk membuat sebuah planning terkait dengan finansial yang akan datang (Melisa Munoz, 2019). Literasi keuangan dapat dikatakan sebagai kewajiban untuk seseorang untuk tidak mengalami kesalahan dalam keuangan karena masyarakat atau dihadapkan suatu kondisi dimana terkadang harus memilih demi untuk hal atau aktivitas yang lainnya (Arsanti, 2018). Chen dan Volpe, bahwa faktorfaktor dalam Literasi keuangan di bagi ke dalam empat (4) aspek yaitu (Ulfatun et al, 2016):

1. Basic financial concept. Pengetahuan dasar dalam beberapa hal yang erat kaitannya dengan pemahaman atau pengetahuan umum/dasar mengenai keuangan pribadi.

2. Tabungan dan pinjaman, Pemahaman masyarakat berhubungan pinjaman ataupun tabungan yaitu penggunaan tabungan pensiun, tabungan pendidikan anak dan tabungan untuk hari tua.

3. Asuransi, berkaitan dengan pengetahuan dan pemahaman masyarakt terkait dengan asuransi seperti asuransi rumah, asuransi kesehatan dan asuransi pendidikan anak

4. Investasi, pada tahap investasi ini memberikan pemahaman tentang investasi dapat dilaksanakan masyarakat seperti investasi efek, investasi emas, tingkat pengembalian yang di harapkan.

Risiko investasi dapat dikatakan sebagai kemungkinan akan terjadinya suatu perbedaan antara tingkat pengembalian dengan yang sesungguhnya (Tandelilin, 2017: 101). Seseorang yang akan menggunakan atau akan memilih sesuatu, tentunya akan melakukan pertimbangan tentang kerugian dan keuntungan yang akan diterima nantinya. Berkaitan dengan Persepsi risiko merupakan pendapat atau persepsi konsumen tentang suatu ketidakpastian dan adanya konsekuensi-konsekuensi yang kemungkinan bisa terjadi pada waktu melakukan kegiatan.

Adapun indikator dari persepsi terhadap risiko (Nyoman et al., 2018):

1. Ada risiko tertentu

2. Mengalami kerugian

3. Pemikiran beresiko

\section{Minat Investasi}


Minat dapat diartikan bahawa suatu perasaan dimana lebih menyukai ataupun lebih tertarik pada sesuatu atau kegiatan, dan dilakukan tanpa adanya perintah. Minat bisa di jelaskan untuk sifat keinginan dari dalam diri seseorang terhadap hal yang menjadi tujuan atau keinginan. Keinginan akan sesuatu adalah suatu perilaku yang sifatnya tidak menetap. (Merawati \& Putra, 2017). Minat diukur dari proses keikutsertaan pada sesuatu kegiatan atau aktivitas yang digemari dan diinginkan (Taufiqoh et al., 2019).

Krapp et all (1996) dalam (Nyoman et al., 2018) dikelompokkan ke dalam dua jernis adalah: 1) Minat Personal, merupakan kondisi dimana adanya ciri-ciri personal masyarakat, sifat keperibadian yang relatif stabil dan terakhir karakteristik individu. Umumnya dikatakan pada kegiatan atau sasaran yang lebih khusus; 2) Minat situasional, untuk jenis ini akan memiliki suatu perbedaan dengan keinginan dikarenakan minat situasional kemungkinan mempunyai hubungan yang eratpada beberapa kegiatan yang lebih khusus dibandingkan pada berbagai aplikasi atau lingkungan. Ada tiga indikator yang minat investasi yaitu (Susanti et al., 2018):

a. Motivasi sesorang yang berasal dari dalam diri seseorang

b. Adanya motivasi sosial

c. Adanya dorongan emosional individu

\section{METODE PENELITIAN}

Dalam penelitian ini digunakan beberapa teori-teori untuk menunjang pengembangan dan pemecahan dari permasalahan yang diteliti mengenai pengetahuan investasi, motivasi investasi, literasi keuangan, persepsi resiko dan minat investasi. Langkah selanjutnya adalah melakukan pengumpulan data yaitu dengan mengunakan berupa kuesioner dari responden pada dua kecamatan yaitu kecamatan sagulung dan batu aji. Selanjutnya langkah yang dilakukan dengan data yang sudah terkumpul dilakukan langkah metode analisis data, selanjutnya langkah atau tahapan terakhir yaitu menarik suatu kesimpulan sesuai dengan hasil penelitian. Populasi pada penelitian yang dilakukan adalah masyarakat Kota Batam yang telah atau pernah melakukan investasi berjumlah 204. Teknik pengumpulan data yang akan diguanakan pada penelitian ini yakni interview, kuesioner, observasi. Penelitian yang dilakukan mengunakan analisis PLS, metode ini digunakan dalam menguji hipotesis yang ada pada penelitian yang diajukan. Tahapan dalam analisis data pada penelitian yang dilakukan ini masing masing hipotesis akan di lakukan analisis dengan mengunakan smartPLS 2.0 dalam menguj bagaimana analisis dari beberapa variabel

\section{HASIL DAN PEMBAHASAN}


Prosiding The 1st National Conference on Applied Business, Education, \& Technology (NCABET)"

Unversitas Bina Bangsa 2021

DOI Article : 10.46306/ncabet.v1i1.41

Responden pada penelitian ini adalah masyarakat Kota Batam yang pernah melakukan investasi dan berminat berinvestasi di Kecamatan Sagulung. Jumlah kuesioner yang disebarkan sejumlah 204 kuesioner. Berikut ini merupakan data profil para responden yang telah ikut serta dalam pengisian kuesioner yang telah dibagikan. Profil responden akan dikategorikan berdasarkan jenis kelamin, umur, pendidikan, pendapatan dan kecamatan. Selanjutnya dilakukan dilakukan analisis analisis deskriftif. Dalam pendekatan SEM/PLS, sebuah pengukuran telah memenuhi validitas konvergen jika memenuhi beberapa syarat. Dengan (a) Memiliki reliabilitas indikator/aitem minimal 0.5, (b). Memiliki reliabilitas komposit lebih tinggi dari 0.7. (c). Rerata varians terekstrasi (AVE) minimal 0.5. Pada Validitas konvergen (Convergent Validity) dipergunakan untuk mengetahui bagaimana validitas setiap hubungan antara indikator dengan konstruk maupun variabel latennya. Untuk menguji convergent validity menggunakan nilai outer loading atau loading factor. Suatu indikator dapat dikatakan memenuhi convergent validity sebagai golongan yang baik apabila nilai outer loading $>0,7$. Berikut adalah tabel hasil kalkulasi model SEM SmartPLS, selanjutnya dapat dilihat nilai loading factor indikator-indikator pada variabel berikut:

Tabel 2 Outer loadings

\begin{tabular}{|c|c|c|}
\hline Variabel & Indikator & Outer Loading \\
\hline \multirow{4}{*}{ Motivasi Investasi } & X1.1 & 0.81432 \\
\cline { 2 - 3 } & $\mathrm{X} 1.2$ & 0.85129 \\
\cline { 2 - 3 } & $\mathrm{X} 1.3$ & 0.85421 \\
\cline { 2 - 3 } & $\mathrm{X} 1.4$ & 0.86431 \\
\cline { 2 - 3 } & $\mathrm{X} 1.5$ & 0.87412 \\
\hline & $\mathrm{X} 1.6$ & 0.83478 \\
\hline Financial Literacy & $\mathrm{X} 2.1$ & 0.82588 \\
\hline & $\mathrm{X} 2.2$ & 0.90237 \\
\hline & $\mathrm{X} 2.3$ & 0.90616 \\
\hline & $\mathrm{X} 2.4$ & 0.82009 \\
\hline & $\mathrm{X} 2.5$ & 0.89481 \\
\hline & $\mathrm{X} 2.6$ & 0.90245 \\
\hline & $\mathrm{X} 3.1$ & 0,90720 \\
\hline Persepsi resiko & $\mathrm{X} 3.2$ & 0,76544 \\
\hline
\end{tabular}

Sumber: Hasil Pengolahan SmartPLS, 2021

Berdasarkan data dalam tabel 1 di atas, diketahui bahwa masing-masing indikator variabel penelitian banyak yang memiliki nilai outer loading $>0,7$. Data di atas menunjukkan tidak ada indikator variabel yang nilai outer loading-nya di bawah 0,5 , sehingga semua indikator dinyatakan layak atau valid untuk digunakan penelitian dan dapat digunakan untuk analisis lebih lanjut. Hal ini menyatakan bahwa memiliki tingkat validitas yang tinggi, sehingga memenuhi convergent validity. Dengan demikian analisis dapat diteruskan pada uji Discriminant Validity. 
Berdasarkan hasil pengujian Discriminant Validity bahwa masing-masing indikator pada variabel penelitian memiliki nilai cross loading terbesar pada variabel yang dibentuknya dibandingkan dengan nilai cross loading pada variabel lainnya. Berdasarkan hasil yang diperoleh tersebut, dapat dinyatakan bahwa indikator-indikator yang digunakan dalam penelitian ini telah memiliki discriminant validity yang baik dalam menyusun variabelnya masing-masing. Selain meneliti nilai cross loading, discriminant validity juga dapat diketahui melalui metode lain yaitu dengan cara melihat nilai average variant extracted (AVE) untuk masing-masing indikator nilainya harus $>0,5$ agar dapat dikatakan sebagai model yang baik.

Tabel 3 Average Variant Extracted (AV
\begin{tabular}{|c|c|}
\hline Variabel & AVE \\
\hline Motivasi Investasi & 0.77198 \\
\hline Financial Literacy & 0.72466 \\
\hline Persepsi resiko & 0.70446 \\
\hline Minat Investasi & 0.83589 \\
\hline
\end{tabular}

Sumber: Hasil pengolahan SmartPLS 3, 2021

Composite Reliability merupakan bagian yang digunakan untuk menguji nilai reliabilitas indikator-indikator pada suatu variabel. Suatu variabel dapat dinyatakan memenuhi composite reliability apabila memiliki nilai composite reliability $>0,6$. Berikut ini adalah nilai composite reliability dari masing-masing variabel yang digunakan dalam penelitian ini:

Tabel 4 Composite Reliability

\begin{tabular}{|c|c|}
\hline Variabel & Composite Realibility \\
\hline Motivasi Investasi & 0.94405 \\
\hline Literasi keuangan & 0.94418 \\
\hline Persepsi resiko & 0.82558 \\
\hline Minat Investasi & 0.93856 \\
\hline
\end{tabular}

Sumber : Hasil pengolahan SmartPLS 3, 2021

Berdasarkan sajian data pada tabel 3 di atas, dapat diketahui bahwa nilai composite reliability semua variabel penelitian > 0,6. Hasil ini menunjukkan bahwa masing-asing variabel telah memenuhi composite realibility sehingga dapat disimpulkan bahwa keseluruhan variabel memiliki tingkat realibilitas yang tinggi.

Tabel 5 Cronbach Alpha

\begin{tabular}{|c|c|}
\hline Variabel & Cronbach Alpha \\
\hline Motivasi Investasi & 0.92522 \\
\hline Literasi keuangan & 0.92774 \\
\hline Persepsi resiko & 0.89521 \\
\hline Minat Investasi & 0.90169 \\
\hline
\end{tabular}


Prosiding The 1st National Conference on Applied Business, Education, \& Technology (NCABET)"

Unversitas Bina Bangsa 2021

DOI Article : 10.46306/ncabet.v1i1.41

Sumber: Hasil pengolahan SmartPLS 3, 2021

Berdasarkan sajian data di atas pada tabel 4.18, dapat diketahui bahwa nilai cronbach alpha dari masing-masing variabel penelitian > 0,7. Dengan demikian hasil ini dapat menunjukkan bahwa masing-masing variabel penelitian telah memenuhi persyaratan nilai cronbach alpha, sehingga dapat disimpulkan bahwa keseluruhan variabel memiliki tingkat reliabilitas yang tinggi. Berdasarkan pengolahan data yang telah dilakukan, hasil dari pengolahan data dapat digunakan untuk menjawab hipotesis pada penelitian ini. Uji hipotesis pada penelitian ini dapat dilihat melalui nilai T-Statistics dan nilai T-Tabel. Hipotesis pada penelitian ini dapat dinyatakan diterima apabila nilai T-Tabel > 1,96. Untuk menilai signifikansi model, dapat dilihat dari nilai $t$-statistic antara variabel independen ke variabel dependen dalam tabel Path Coefficient pada output SmartPLS dibawah ini:

Tabel 6 T-Statistic

\begin{tabular}{|c|c|c|c|c|c|}
\hline & $\begin{array}{c}\text { Original } \\
\text { Sample } \\
(\boldsymbol{O})\end{array}$ & $\begin{array}{c}\text { Sample } \\
\text { Mean }(\mathbf{M})\end{array}$ & $\begin{array}{c}\text { Standard } \\
\text { Deviation } \\
(\text { STDEV })\end{array}$ & $\begin{array}{c}\text { T Statistics } \\
(\mid \mathbf{O} / \text { STDEV|) }\end{array}$ & P Values \\
\hline $\begin{array}{c}\text { Literasi Keuangan - } \\
\text { > Minat Investasi }\end{array}$ & 0,58081 & 0,47590 & 0,15167 & 3,39217 & 0,00376 \\
\hline $\begin{array}{c}\text { Motivasi Investasi - } \\
\text { > Minat Investasi }\end{array}$ & 0,41050 & 0,42095 & 0,15878 & 2,89592 & 0,004680 \\
\hline $\begin{array}{c}\text { Persepsi resiko -> } \\
\text { Minat Investasi }\end{array}$ & 0,51806 & 0,61134 & 0,13347 & 2,88450 & 0,00376 \\
\hline
\end{tabular}

Sumber: Hasil pengolahan SmartPLS 3, 2021

Dari tabel 6 diatas, hubungan antara Motivasi Investasi dengan minat investasi adalah signifikan dengan T-Statistics berada diatas 1,96 yaitu sebesar 2,89592 Nilai original sample (O) adalah positif yaitu sebesar 0,41050 yang menjelaskan bahwa hubungan antara Motivasi investasi terhadap Minat investasi adalah positif. Dengan demikian, hipotesis H1 dalam penelitian ini yang menjelaskan bahwa "Motivasi Investasi berpengaruh terhadap Minat investasi" diterima.

Hubungan antara literasi keuangan dan minat investasi adalah signifikan dengan $\mathrm{T}$ Statistics berada diatas 1,96 yaitu sebesar 3,39217. Nilai original sample $(\mathrm{O})$ adalah positif yaitu sebesar 0,58081 yang menjelaskan bahwa hubungan antara literasi keuangan dan minat investasi adalah positif. Dengan demikian, hipotesis H3 dalam penelitian ini yang menjelaskan bahwa literasi keuangan dan minat investasi” diterima.

Hubungan antara Persepsi resiko dan keputusan investasi adalah signifikan dengan TStatistics berada diatas 1,96 yaitu sebesar 2,88450. Nilai original sample $(\mathrm{O})$ adalah positif yaitu sebesar 0,51806 yang menjelaskan bahwa hubungan antara Persepsi resiko dan minat investasi 
adalah positif. Dengan demikian, hipotesis H3 dalam penelitian ini yang menjelaskan bahwa persepsi resiko dan minat investasi” diterima.

\section{HASIL DAN PEMBAHASAN}

\section{Pengaruh motivasi investasi terhadap minat investasi}

Berdasarkan hasil dari perhitungan statistik, dapat disimpulkan bahwa motivasi investasi berpengaruh positif dan signifikan terhadap minat investasi secara langsung. Hal ini dapat diketahui dari nilai T-Statistic yang lebih besar dari 1.96 yaitu sebesar 2,89592. Nilai original sample $(\mathrm{O})$ adalah positif yaitu sebesar 0,41050. Dengan demikian, hipotesis H1 dalam penelitian ini diterima. Motivasi investasi mempunyai hubungan yang searah dengan minat investasi. Semakin meningkatnya motivasi masyarakat berinvestasi maka minat masyarakat berinvestasi mengalami peningkatan.. Hasil ini sesuai dengan hasil penelitian (Darmawan et al., 2019) yang mengatakan bahwa motivasi investasi berpengaruh terhadap minat investasi.

\section{Pengaruh literasi keuangan terhadap minat Investasi}

Berdasarkan hasil dari perhitungan statistik, dapat disimpulkan bahwa Literasi Keuangan berpengaruh positif dan signifikan terhadap minat investasi secara langsung. Hal ini dapat diketahui dari nilai T-Statistics berada diatas 1,96 yaitu sebesar 3,39217. Nilai original sample (O) adalah positif yaitu sebesar 0,58081 yang menjelaskan bahwa hubungan antara literasi keuangan dan minat investasi adalah positif. Hal ini menjelaskan bahwa adanya pengaruh yang signifikan antara literasi keuangan dengan minat investasi. Rendahnya pengetahuan keuangan berpengaruh terhadap perencanaan keuangan di masa depan, sedangkan ketidaktahuan tentang konsep dasar keuangan dapat berhubungan dengan rendahnya perencanaan investasi. Semakin tinggi tingkat pengetahuan keuangan (literasi keuangan) seseorang, maka semakin bijak dalam menentukan minat investasi. Hasil ini sesuai dengan hasil penelitian (Wulandari, 2016) yang mengatakan bahwa literasi keuangan berpengaruh terhadap minat investasi.

\section{Pengaruh persepsi resiko terhadap keputusan Investasi}

Berdasarkan hasil dari perhitungan statistik, dapat disimpulkan bahwa persepsi resiko berpengaruh positif dan signifikan terhadap minat investasi secara langsung. Hal ini dapat diketahui dari nilai T-Statistics berada diatas 1,96 yaitu sebesar 2,88450. Nilai original sample (O) adalah positif yaitu sebesar 0,51806 yang menjelaskan bahwa hubungan antara Persepsi resiko dan minat investasi adalah positif. Dengan demikian, hipotesis H4 dalam penelitian ini diterima. Hasil penelitian ini secara empiris menunjukkan bahwa masyarakat lebih tertarik melihat return (pengembalian) yang ditawarkan, sehingga persepsi mereka atas resiko juga tinggi. Hasil penelitian ini didukung oleh penelitian Malik (2017) yang menyatakan bahwa semakin tinggi resiko maka minat investor untuk berinvestasi semakin meningkat. 
Prosiding The 1st National Conference on Applied Business, Education, \& Technology (NCABET)"

Unversitas Bina Bangsa 2021

DOI Article : 10.46306/ncabet.v1i1.41

\section{KESIMPULAN DAN SARAN}

Adapun kesimpulan dari penelitian ini adalah (1) Motivasi Investasi berpengaruh secara signifikan dan positif terhadap minat investasi Kota Batam, (2). Literasi keuangan berpengaruh secara signifikan dan positif terhadap minat investasi Kota Batam, (3). Persepsi resiko berpengaruh secara signifikan dan positif terhadap minat investasi di Kota Batam.

\section{UCAPAN TERIMA KASIH}

Penulis mengucapkan terimakasih kepada Allah SWT yang telah memberikan rahmat dan kemampuan sehingga penelitian ini dapat terselasaikan dengan baik. Penulis juga mengucapkan terima kasih yang sebesar-besar kepada kepada Tim Panitia NCBET yang telah menginisiasi acara yang sangat bermanfaat ini.

\section{DAFTAR PUSTAKA}

Arsanti, C. (2018). Analisis Pengaruh Literasi Keuangan Terhadap Perilaku Keuangan Mahasiswa. Perbanas Jurnal, 3(2), 110-122.

Darmawan, A., Kurnia, K., \& Rejeki, S. (2019). Pengetahu Modalan Investasi, Motivasi Investasi, Literasi Keuangan Dan Lingkungan Keluarga Pengaruhnya Terhadap Minat Investasi Pasar. Jurnal Ilmiah Akuntansi Dan Keuangan, 08(02), 44-56.

Listyani, T. T., Rois, M., \& Prihati, S. (2019). Analisis Pengaruh Pengetahuan Investasi , Dan Persepsi Risiko Terhadap Minat Investasi Mahasiswa Di Pasar Modal ( Studi Pada Pt Phintraco Sekuritas Branch Office Semarang ). 2(1), 49-70.

Merawati, L. K., \& Putra, I. P. M. J. S. (2017). Kemampuan Pelatihan Pasar Modal Memoderasi Pengaruh Pengetahuan Investasi Dan Penghasilan Pada Minat Berinvestasi Mahasiswa. Jurnal Ilmiah Akuntansi Dan Bisnis.

Nyoman, N., Rahayu, S., Dewi, T., Fridagustina, K., Herry, G., \& Asana, S. (2018). Modal Investasi Awal Dan Persepsi Resiko Dalam Keputusan Berinvestasi. 2(2), 173-190.

Saputra, D. (2018). Pengaruh Manfaat, Modal, Motivasi Dan Edukasi Terhadap Minat Dalam Berinvestasi Di Pasar Modal. 5(2), 178-190.

Susanti, S., Hasan, M., Ahmad, M. I. S., \& Marhawati. (2018). Faktor-Faktor Yang Mempengaruhi Minat Mahasiswa Berinvestasi Di Galeri Investasi Universitas Negeri Makassar. Prosiding Seminar Nasional Pendidikan Ekonomi.

Taufiqoh, E., Diana, N., \& Junaidi. (2019). Pengaruh Norma Subjektif, Motivasi Investasi, Pengetahuan Investasi, Persepsi Return Dan Literasi Keuangan Terhadap Minat Mahasiswa Berinvestasi Saham Di Pasar Modal (Studi Empiris Pada Mahasiswa Akuntansi FEB UNISMA dan UNIBRAW di Malang) Oleh. 08(05), 9-19.

Wulandari, D. A. (2016). Studi experienced Regret, Risk Tolerance, Overconfidance dan risk perception pada pengambilan leputusan investasi Dosen ekonomi. Journal of business and banking, 4(1), 55-66. 